\title{
Establishing True Lifestyle Brand in India: An Integrated Marketing Mix Framework
}

\author{
H. R. Ganesha ${ }^{1}$, \& P. S. Aithal ${ }^{2}$ \\ ${ }^{1}$ Chief Executive Officer - Consulting Division, Gramss Retail Trading Private Limited, Bengaluru \\ - 560078, India and Post-Doctoral Research Fellow, College of Management\& Commerce, \\ Srinivas University, Mangalore - 575001, India. OrcidID: 0000-0002-5878-8844; \\ E-mail: hrganesha@yahoo.co.in \\ ${ }^{2}$ Vice Chancellor, Srinivas University, Mangalore - 575001, India. \\ OrcidID: 0000-0002-4691-8736; E-mail: psaithal@,gmail.com
}

Area/Section: Management.

Type of the Paper: Empirical Research.

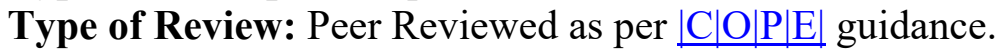

Indexed in: OpenAIRE.

DOI: http://doi.org/10.5281/zenodo.

Google Scholar Citation: IJMTS.

How to Cite this Paper:

Ganesha, H. R., \& Aithal, P. S. (2020). Establishing True Lifestyle Brand in India: An Integrated Marketing Mix Framework. International Journal of Management, Technology, and Social Sciences (IJMTS), 5(1), 261-284. DOI: http://doi.org/10.5281/zenodo.

International Journal of Management, Technology, and Social Sciences (IJMTS) A Refereed International Journal of Srinivas University, India.

(C) With Authors.

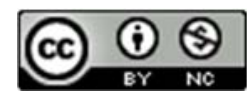

This work is licensed under a Creative Commons Attribution-Non-Commercial 4.0 International License subject to proper citation to the publication source of the work.

Disclaimer: The scholarly papers as reviewed and published by the Srinivas Publications (S.P.), India are the views and opinions of their respective authors and are not the views or opinions of the SP. The SP disclaims of any harm or loss caused due to the published content to any party. 


\title{
Establishing True Lifestyle Brand in India: An Integrated Marketing Mix Framework
}

\author{
H. R. Ganesha ${ }^{1}$, \& P. S. Aithal ${ }^{2}$ \\ ${ }^{1}$ Chief Executive Officer - Consulting Division, Gramss Retail Trading Private Limited, Bengaluru \\ - 560078, India and Post-Doctoral Research Fellow, College of Management\& Commerce, Srinivas \\ University, Mangalore - 575001, India. OrcidID: 0000-0002-5878-8844; \\ E-mail: hrganesha@yahoo.co.in \\ ${ }^{2}$ Vice Chancellor, Srinivas University, Mangalore - 575001, India. \\ OrcidID: 0000-0002-4691-8736; E-mail: psaithal@gmail.com
}

\begin{abstract}
Humongous size of Indian retail market, evolution of modern and external brands friendly retailing formats in addition to attracting many Global lifestyle brands has also prompted many Indian exporters, manufactures, conglomerates and entrepreneurs to launch Indian lifestyle brands. It is evident that only a few Indian brands are able to create true lifestyle brand image in their employees, investors, competitors and consumers mind and the trueness level of the majority of Indian lifestyle brands is still a question. Majority of developing and developed Indian lifestyle brands assume that the success of a lifestyle brand is measured basis the revenue or profit they generate and are impatient and unaware of implicit long- term strategical benefits of creating a true lifestyle brand image in consumers mind. It is true that India is one of the countries with consumers belonging to the widest range of Religions, Regions, Languages, Sub-Cultures and Economic backgrounds which makes it very difficult for any lifestyle brand to own a true lifestyle brand image at National level and makes it furthermore important for them to be more careful and efficient in ensuring adaptation of right Marketing Mix. It is observed that the majority of Indian lifestyle brands believe they have adopted the right Marketing Mix and it is yielding the best possible revenue and profit. This belief/assumption always distracts them from working on their existing Marketing Mix and they rather spend most of their time in finding elements which are new or latent in nature to be added to the existing Marketing Mix. In this research work, we have evaluated existing Marketing Mix of few select Indian lifestyle brands across various product categories and consumer target groups to design a new Marketing Mix by just rationalizing and re-prioritizing all the elements and sub elements of basic "4P's" of McCarthy's original 'Marketing Mix' proposition along with taking clues from Lavidge and Steiner's original 'Hierarchy of Effects Model'.
\end{abstract}

Keywords: Indian Retail, National Brand, Lifestyle Brand, Indian Lifestyle Brand, Marketing Mix, Retailing Format Mix, Sales Personnel Empowerment, Decentralization, Brand Image.

\section{INTRODUCTION :}

Each individual wants to have a unique identity that could be based on his/her (a) background such as nationality, ethnicity, culture, subculture, social class, affiliation, environment, etc; (b) experiences, and (c) choices. Lifestyle brands in fact attempt to evoke emotional connections between consumers and their need to have a unique identity and most importantly lifestyle brands are increasingly becoming one of the key components of consumer's self-expression [1].To ensure the scope of this study is focussed, we define lifestyle brands as the ones, which attempt to offer a complete solution for a specific or wider lifestyle needs of consumers through their products such as Apparel, Footwear, and Accessories with an ultimate goal of their products being key contributors of an implicit 
or explicit statement of consumers personality and identity. Lifestyle retail market size in India is expected to reach 130 billion USD by the year 2023 which is a 77 percent growth when compared to the year 2013 [2]. Based on India's 2011 census, United Nation's (UN) Department of Statistics and Programme Implementation estimates the Indian population to reach close to 1.38 billion by the year 2020[3]. It is estimated that more than 300 Global lifestyle brands have plans to open their stores in India this year [4]. In addition to this humongous population, exponential growth in the number of working women, double income families, middleclass consumer segment, increasing disposable income, rapid adoption of fashion, urbanization, overall size of Indian retail industry, more and more unorganized retailers becoming organized, emergence of modern retailing formats and most importantly enormous increase in internet penetration/usage, simply caution existing and upcoming lifestyle brands to revisit their existing Marketing Mix.

1.1 Global Lifestyle Brands in India: Owing to the sheer market size and potential, India is able to attract many global lifestyle brands. Few Global brands have attempted to offer their product assortment as being a shop-in-shop at select large retail format stores, few have offered their product assortment through having EBOs, few have shown their presence only in the online store and few have licensed their brands to third parties or entered into a Joint Venture to offer their products in Indian retail market. To name a few Levi's, Zara, United Colors of Benetton, Marks \& Spenser, H\&M, Mother Care, Carter's, Puma, Nike, Adidas, Reebok, Armani Exchange, Diesel, Gas, Gap, The Children's Place, Quiksilver, Superdry, Kappa, Bossini, Calvin Klein, Hanes, Tommy Hilfiger, Ed Hardy, Izod, Nautica, Arrow, U.S. Polo Assn, Jack \& Jones, Vero Moda, Tumi, Lee, Hero, Maverick, Wrangler, Filaand Jockey. Unless these Global lifestyle brands explore sourcing their products predominantly from India, competitive pricing remains one of the key challenges as far as their sustainable success in the Indian market is concerned.

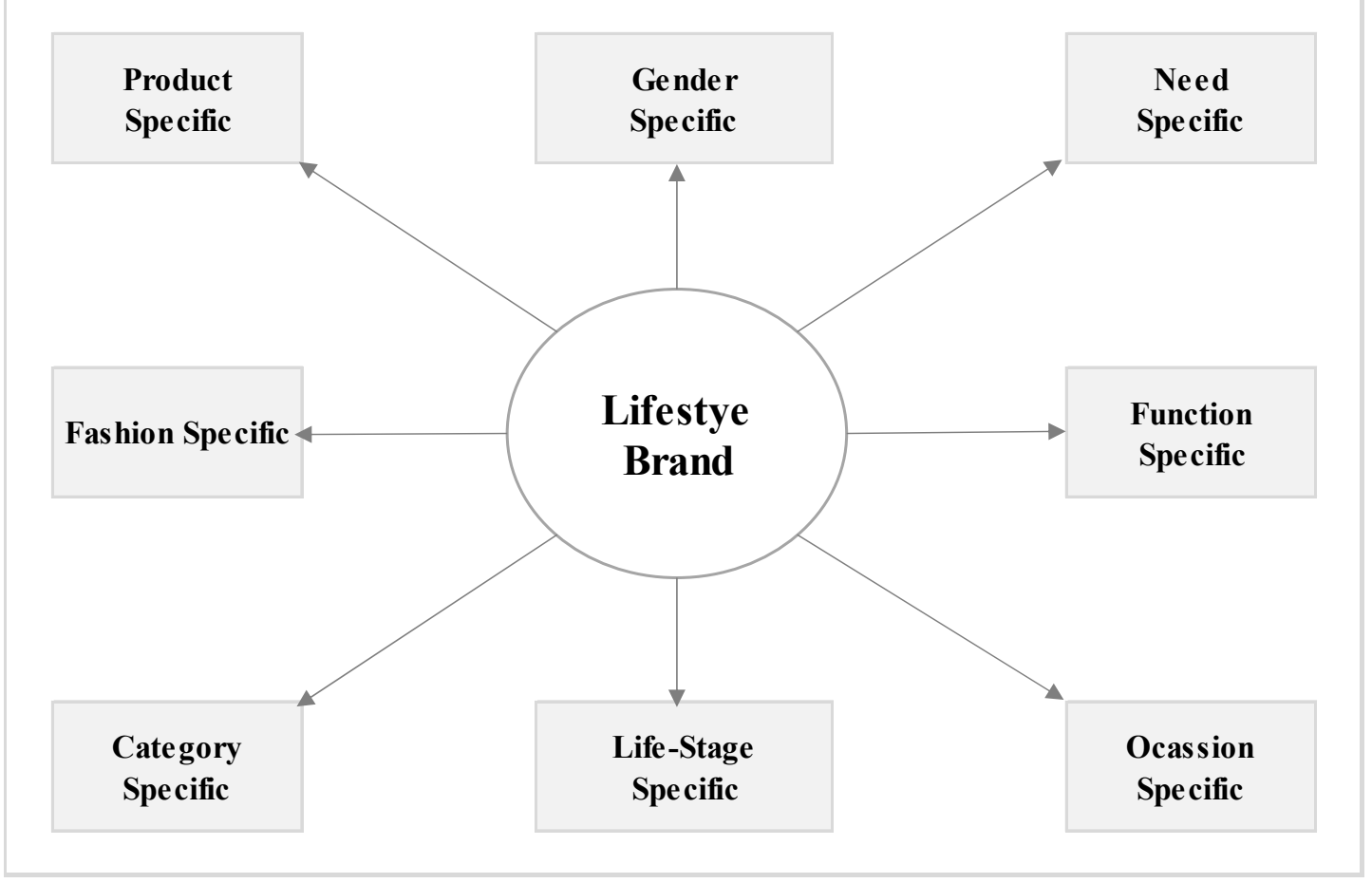

Fig. 1: Product offering by lifestyle brands in India. 
1.2 Indian Lifestyle Brands: India has a vast number of lifestyle brands originated from India. One can possibly list more than 5000 lifestyle brands in India [5], of which few of them have strong presence all over India, few have a strong presence only in certain regions of India and few are available only online. It is evident that, in spite of such humongous number of lifestyle brands available in India one could possibly list only a few which can be tagged as well-known / familiar / reputed Indian lifestyle brands such as, Biba, Manyavar, Soch, Gini \& Jony, Blackberrys, Louis Phillipe, Peter England, Provogue, Monte Carlo, Mufti, W for Women, Oxemberg, Indian Terrain, Global Desi, Parx, S Kumar's, Vimal, Mini Klub, Aurelia, Sparx, Campus, Go Colors, Enamour, HiDesign, Lino Perros, Idee, Spykar, Killer Jeans, Flying Machine, Da Milano, Park Avenue, Ethnix, ColorPlus, Lux Cozy, Wild Craft, 612 League, WLS, John Players, Fastrack, 109 F, Proline, Image, Jealous 21, Liberty, Paragon and few more. Only few names from the list of more than 5000 brands possibly indicating that in spite of humongous population and the retail market size in India, majority of Indian lifestyle brands have failed to establish themselves as true lifestyle brands. We attribute this failure majorly to the Marketing Mix being adopted by these brands in addition to unorganized brands and retailers still having majority of the share in Indian retail market. Figure 1 depicts the product offering of typical lifestyle brands in India. Dominantly majority of lifestyle brands in India offer just one of these and a very few caters to multiple products offering to multiple consumer groups.

\section{LITERATURE REVIEW :}

2.1 Marketing Mix: concept in literature can be traced back to 1940's and can be attributed to Borden, N.H. [6] as the first one to mention such a concept in general. Later in 1960's Edmund Jerome McCarthy gave a framework to basic elements of Marketing Mix which is globally known as "4P's" of Marketing Mix of which, the first one being 'Product', second one being 'Price', third one being 'Promotion' and the fourth one being 'Place'. Many researchers through their studies have criticized the "4P's" Marketing Mix concept arguing that the framework has shortcomings and only suitable for traditional marketing strategies [7 - 10]. However, many studies have provided their consensus that "4P's" framework of Marketing Mix is a powerful tool in marketing till today and they have been used by the majority of management practitioners and researchers [11]. Many researchers across domains such as Marketing Theory, Relationship Marketing, Services Marketing, Retail Marketing, Industrial Marketing and Online Marketing, whether or not agreeing to the "4P's" framework have continuously suggested many additional elements to be added to the original " $4 \mathrm{P}$ 's" framework and proposition of Marketing Mix of which few key elements are; Political Power and Public Opinion Formulation [12]; Customers, Competitors and Corporation [13]; Capabilities [14]; Mapping of Marketing Mix Elements [15]; Services and Staff [16]; Value, Viability, Variety, Volume and Virtue [17]; Performance, Penalty, Perceptions and Process [18]; Marketing Triad Marketer, Employee and Customer [19]; Customer Orientation, Customer Needs, Convenience, Customer's Cost and Communication [20]; Product Extras, Reinforcing Promotions, Sales-Force Connections, Specialized Distribution and Post-Purchase Communication [21]; Relationships, Network, and Interaction [22]; Relationship Marketing [23]; Personalisation, Personnel, Physical Assets and Procedures [24]; Communication, Customisation, Collaboration and Clairvoyance [25]; Relationships, Neo-Relationship and Networking [26]; Participants, Physical Evidence and Process [27 to 28]; Concept Mix, Cost Mix, Channels Mix, Communication Mix [29]; Intangibility, Inseparability, Perishability and Variability of Services [30]; Differentiation, Customer Contact and Unique Vision on Quality Parameter [31]; Personnel [32]; Communication and Distribution [33]; Publications [34]; Relevance, Response, Relationships and Results [35]; Actors, Audience, Setting and Performance [36]; Brand, Packaging and Relationships [37]; Logistic Concept and Commercial Concept [38]; Assortment, Shop Presentation, Price Policy, Personnel [39]; Store Location, Store Positioning, Store Image, Physical Environment and Retail Service [40]; Data Base, Interaction and Network [41]; Target Market, Product Assortment cum Procurement, Services cum Store Atmosphere, Price Decision and Place Decision [42]; Quality and Degree of interdependence among business to business organisations [43]; International 
Elements [44]; Customer Service, Teamwork, Service Quality and Service Excellence [45]; Relationships and Networks Management [46]; CoDesign cum Production, Transparent Pricing, Direct Contacts with Customers, Control of the Customer Interaction [47]; Change in roles of basic "4P's" to align with Ecommerce [48]; Website design based on Who, What, When, Where and Why [49]; Web Planning, Web Access, Web Implementation, Wb Management and Evaluation [50]; Potential Audience, Integration, Marketing Support, Brand Migration, Strategic Partnership, Organization Structure and Budget [51]; Paradox, Perspective, Paradigm, Persuasion and Passion [52]; Technology [53]; Scope, Site, Synergy and System [54].

2.2 Retailing in general has been one of the key interest areas of study for many researchers around the world for many years. It is strongly argued that profitability is significantly derived from consumer loyalty which is strongly linked to internal service quality, satisfied and productive service employees. The service-profit chain model created holds true even after globalization, liberalization, and digitization of the retail market [48]. Few studies have listed the key components of store image construct. Based on past studies Lindquist listed eight component of store image construct viz., (i) merchandise, (ii) clientele, (iii) physical facilities, (iv) convenience, (v) promotion, (vi) store atmosphere, (vii) institutional factors and (viii) post-transactional satisfaction [55]. Later studies were also able to add few more attributes to store image constructs such as (ix) customer service, (x) personal selling and (xi) sales incentive programs [56]. Various indicators which can determine a retail sale in relation to quality and level of sales personnel involvement have been studied and analysed by many researchers of which, most important indicators were (a) the amount and quality of time spent by the sales personnel with the consumer [57]; (b) variety of products/SKUs/models being showcased by the sales personnel to consumer [58]; (c) level of information being collected by the sales personnel on consumer needs directly from the consumer [59]; (d) sales person's efforts to understand the consumer brand preference and showcasing products/SKUs/models in relation to the preference [60]; (e) sales personnel's capability to explain the features of products showcased to consumers and their confidence level while explaining the differentiation among a variety of products showcased [61] and (f) the range of products/SKUs/models showcased by the sales personnel in relation to price and utility expected by the consumer [62]. Another important aspect in retailing which has a significant impact on consumer repeat visit intention and loyalty for a retail store is the sales personnel's perception and predisposition about a consumer who he/she is attending to. The majority of sales personnel develop their mindsets to segment consumers into preferred consumers and non-preferred consumers and this mindset plays an important role in the way the consumer would get treated by the sales personnel [63 to 65]. Few studies believe that the way in which sales personnel interact with consumers needs to be customized to each consumer and this could possibly be able to determine their success. The customer orientation is said to happen when the sales personnel and consumer together practice the marketing concept. They have clearly stated that just the interaction between sales personnel and consumer does not yield to this orientation, it needs to encompass most of the marketing concepts driven centrally by the company [66 to 67]. Later, this definition of consumer orientation was further narrowed down by coming up with two key constructs, the first one being sales personnel's tendency to ensure consumer needs are met and the second one being the level of sales personnel's enjoyment in doing so [68]. It is also believed that what can lead to sales personnel to enjoy the process of interaction with consumers and ultimately selling a product is their strong orientation to learning [69]. It is also important to note, various studies have shown that $70 \%$ of the purchase decisions are made in-store by most of the customers [70]. Researchers have also defined price image as "buyer attitude towards a price on the assortment level" [71]. Studies find that the zone-level pricing among stores at a different location belonging to a same retailer or brand is mainly motivated by price discrimination [72], overall store / brand price image is developed in consumers mind by combining general price perceptions in relation to individual product/brand available in a retail store [73] and multi-location retailers can continue to have differential pricing strategies for different locations 
and geographies but at the same time, they need to clearly understand that this differential pricing strategy has an impact on both overall profitability and consumer welfare [74]. It is true that store location plays an influential role in consumer store choice decisions, at the same time store location being a long-term capital lock-in decision plays an important role in the retailer's overall strategic planning. Any location which has inherent properties of attracting consumers is the best location for any retailer and having a store in such locations brings both strategic and competitive advantages to the retailer, whereas, it will take longer time and huge store losses for any retailer to come out of a bad store location. Good store location could also be analysed by; (a) the amount of relevant consumer traffic flow, be it pedestrian traffic or vehicular traffic; (b) parking facilities; (c) store composition; (d) specific site; (e) terms of occupancy, (f) accessibility, (g) travelling time, (h) location convenience, (i) other complimentary stores present in the catchment [75]. Researchers have argued that it is no more just merchandising, which is important for successful retailing, what is becoming more and more important nowadays is other aspects of store operations which include various other aspects including inventory management [76]. We have also noted that, for many, the choice of store format was and is one of the important research subjects among many researchers beginning from the 70's of the 20th century. The authors of many of earlier studies have attempted to rationalize store choice using different approaches, models and frameworks with respect to internal and external factors to the consumer such as (a) store attributes (b) situational factors, (c) consumers' households, (d) consumers' demographics, (e) consumers' shopping patterns, (f) consumers' attitudes toward stores, (g) implied importance, and (h) weightage of price levels and (i) the brand. It is also noted that most of the store choice studies were carried on same store formats viz., i) supermarkets, ii) discount stores[77 to 85].It is imperative to understand the existing literature, theories, models and frameworks on retailing across formats, as a significant proportion of lifestyle brand's success in establishing itself as a true lifestyle brand in the consumers mind is moderated by brand's and consumer's choice of retailing format also. Retailing in India has gone through many stages of evolution such as liberalization, organized retailing, globalization, digitalization, and urbanization. Retailing in India was and is heavily driven by unorganized retailers and the same is evident by the sheer market share it owns even today in spite of Indian retailing have had gone through various stages of evolution. Various studies report a favourable and improving market share for organized retailers. Organized retailing in India is expected to have approximately 25 percent of the market share by the year 2021 which was at 12 percent in the year 2017 [86]. We believe that the unorganized retailers also have evolved over a period of time in modifying their Marketing Mix to adopt changing consumer mindset and growing competition from organized retailers, thus one can attribute the slow penetration of organized retailing in India to this open mindset of unorganized retailers to constantly work on their Marketing Mix. In turn, this becomes a classic example of considerable magnitude to confirm that the "4P's" framework of McCarthy which was conceptualized sixty years ago holds true even today in India. One could argue that, if unorganized retailers begin to turn in to even semi-organized retailers, then it really poses significant challenges to organized retailers in India to cope up with unorganized retailers in India. It becomes inevitable for organized retailers to keenly focus on their Marketing Mix strategies and strive to create differentiation across various elements of Marketing Mix.

2.3 Consumer preference or choice of brand and the success of a brand depends upon the brand's personality. It is important for the marketer to constantly work on strategies to convert the existing brand image into equity [87].Few researchers have investigated the correlation among the competition of brands, formation of consumers' attitude and intention to choose a particular brand or alternatives being offered to the consumers at a given point of time and the place of the offering. Findings of these studies confirm that consumers' evaluations, understandings, and knowledge about a particular brand of their choice are not just the key influencer of creating intentions of buying a product belonging to a brand, it is also consumers' perspectives and perceptions toward another alternative or brand available in the offering [88].There are few brands 
which have gained strong brand equity owing to consumers having special, favourable association with such brands in their memories and these brands were able to create higher perceived quality, awareness about the brand name and ultimately leading huge loyal consumers over a period of time [89 to 91]. Consumers tend to correlate their personality with the brand personality they are willing to associate with, wherein they attribute this to their demographic characteristics, physical characteristics, personal traits and, cognitive abilities consequently leading them to buy a brand's product to implicitly or explicitly express / showcase their personal image or identity [92 to 93]. Abundant literature is available on Brand personality, image, equity, experience, association, advertisement, endorsements, and loyalty as a result of contributions from many researchers across domains.

We believe that Lavidge and Steiner's original 'hierarchy of effects model' conceptualized during 1960 's, that the consumer's journey of purchase decision begins with 'Awareness', flows through 'Knowledge', 'Liking', 'Preference', 'Conviction', and ends with a 'Purchase' [94] which was later used in the consumer loyalty studies whereby researchers extended this six-stage model further by adding two more elements such as Repeat Purchase and Referring the brand / product / service to others post-Purchase. This model and framework are still relevant, and we intend to use the basic principles of these models in this study. We also determinedly believe that all the new elements suggested by various researchers were inherent elements within "4P's" proposition which was originally framed by McCarthy sixty years ago and therefore through this research study we intend to customize the original "4P's Marketing Mix framework to Indian lifestyle brands adopting which they could possibly overcome the challenges they are facing due to their existing Marketing Mix and establish themselves as true lifestyle brands in consumer's mind.

Need for this research indeed was originated due to various gaps found in the theoretical, descriptive, empirical literature available in the Marketing Mix domain such as; a) majority of studies have focussed on few 'P's of the Marketing Mix and predominantly on 'Promotion' element; b) majority of Marketing Mix studies have focussed on retailing and brands in general and not specific to lifestyle brands; c) absence of Marketing Mix framework or proposition for a lifestyle brand in Indian context; d) majority of lifestyle brands in the India follow and practice the Marketing Mix incorporated by consumer goods and other generalist brands; and most importantlye) consumers in India now have more retailing formats to choose for their lifestyle shopping needs. Thus, we decided to understand / evaluate the existing Marketing Mix of a few select Indian lifestyle brands chosen across product categories and tried designing a new Marketing Mix framework cum proposition.

\section{OBJECTIVES :}

Key objectives of this research were to(i) understand lifestyle brands market in India; (ii) understand evolution and performance of Indian lifestyle brands; (iii) understand existing Marketing Mix of few select Indian lifestyle brands; (iv) analyse recommendations from previous research studies; (v) design and propose an integrated Marketing Mix framework and (iv) recommend a systematic approach for executing the new Marketing Mix.

\section{METHODOLOGY :}

To ensure a holistic approach to find answers to our key research questions, we have adopted a mix of various research methodologies available in the research methods and designs literature as detailed in this section.

4.1 Secondary Research: Intense and in-depth analysis of data available in the public domain was carried to collect data relating to various aspects of lifestyle brands in India through company websites, company annual financial reports, Government database, trade, and business journals. Research works relating to Indian lifestyle brands were surveyed extensively to collect insights, recommendations, and frameworks.

4.2 Quantitative Primary Research: In the first stage, few lifestyle brands in India were selected who can represent a) different product categories such as fashion; functional, life-stage specific, product specific, gender specific, and need specific products; b) offering single-product category, and multipleproduct categories; c) serving different consumer target groups at low, mid-low, mid, mid-high, high, and premium price positioning; d)selling their 
products through local retailers either directly or using distributors, regional retailers either directly or using distributors, national retailers, exclusive brand outlets (EBO) operated directly by the brand, EBOs operated by a franchisee, online EBO store operated either directly or using third parties and online marketplaces; e) products manufactured from own factory, contract manufacturers both inside and outside India; f) across developing brands, developed brands, and, established brands. In the second stage, data was collected from these select lifestyle brands to quantitatively map their existing Marketing Mix and draw inferences.

4.3 Qualitative Primary Research: Series of openended direct interviews were conducted with employees selected through convenience sampling representing different departments/functions from Brands, Distributors and Retailers viz., Human Resource Development, Training, Strategy, Category, Communication, Customer Relationship, Warehousing, Finance, Information Technology, Sales, Distribution, Stores Operation along with Store Sales Personnel to understand their perspective and attitude towards existing Marketing Mix and its implications on the overall brand performance.

\section{PROPOSED MARKETING MIX :}

Before we theoretically design a new Marketing Mix framework or proposition, we thought, it would be ideal to first understand the existing Marketing Mix of select lifestyle brands and evaluate if the same is efficient in establishing a true lifestyle brand image across employees, investors, competitors and consumers mind. In addition to taking clues from the direct interviews of employees representing all the departments and functions, we have analysed the existing sales data, consumer data, terminologies, categorization, key result areas, key performance indicators, data hierarchy, organizational hierarchy, and key business objectives through which we have assessed the attitudes of the entire organization towards existing Marketing Mix in relation to data available.

5.1 Existing Marketing Mix: Figure 2 depicts the existing Marketing Mix which was common across all the Indian lifestyle brands selected for the research study. One can observe that this shows a classical and traditional Marketing Mix wherein, standard "4P's" have been utilized to strategically position the brand. It is perfectly fine not to invent new "P's" but at the same time, the framework seriously ignores the rationalization of each of these " $\mathrm{P}$ ' $\mathrm{s}$ " in accordance with consumers' life-stage needs and forces consumers to patronize with different brands for different needs, occasions, price points and retailing formats. Majority of sub elements of the framework have been derived from standard and general way of categorization which are followed by competitor and could possibly lead all the personnel in the organization also deliver results which are just average or below average thereby seriously failing to achieve true lifestyle brand image.

Majority of the employee roles were defined based on general classification and categorization of products and they were all significantly skewed in favour of supply side capabilities. For instance; (i) an organization is strong in manufacturing or exporting a specific product category and thus decides to launch a domestic lifestyle brand for such product categories in India; (ii) category management team had category managers for specific product categories wherein each of these category managers were concerned about their category profitability level irrespective of its positive or negative impact on the consumer's overall life-time value and satisfaction towards the brand; (iii) retail planning team had planners for specific product categories and retailing formats wherein each of these planners were only concerned about the inventory levels and turns of their product categories and retailing formats rather than the overall inventory mix of the brand and its impact on consumers perception over the brand image; (iv) marketing team had managers for specific category, tasks and retailing formats grouped together and majority of the promotions were designed and communicated to consumers in isolation that too skewed towards announcing discount related promotional activities; (v) sales personnel in the store were allocated specific product categories owing to which the sales pitch to consumers was in silos and the store whether EBO or SIS across retailing formats as a whole could never focus on consumers' life-time value, consumers' complete needs across different product categories and most importantly (vi) the store / brand sales team failed to create positive perceptions in consumer's mind about the brand. 
International Journal of Management, Technology, and Social

\begin{tabular}{|c|c|c|c|}
\hline \multicolumn{4}{|c|}{ Supply Side: Product Category Specific Brand Positioning and Employee Role Definitions } \\
\hline Product & Price & Promotion & Place \\
\hline $\begin{array}{l}\text { Apparel and Footwear: } \\
\text { Casual Wear } \\
\text { Formal Wear } \\
\text { Ethnic Wear } \\
\text { Fusion Wear } \\
\text { Sports Wear } \\
\text { Active Wear } \\
\text { Athleisure } \\
\text { Winter Wear } \\
\text { Occasion Wear } \\
\text { Inner Wear } \\
\text { Sleep Wear } \\
\text { Fashion Eye Wear } \\
\text { Socks \& Stockings } \\
\text { Handbags, Wallets \& Belts } \\
\text { Fashion Accessories } \\
\text { Sports Accessories }\end{array}$ & $\begin{array}{l}\text { Low or } \\
\text { Mid-Low or } \\
\text { Mid or } \\
\text { Mid-High or } \\
\text { High or } \\
\text { Premium }\end{array}$ & $\begin{array}{l}\text { End-of-Season Sale; } \\
\text { Occasional Sale; } \\
\text { Flash Sale; } \\
\text { Clearance Sale; } \\
\text { Cash Back: } \\
\text { Coupons; } \\
\text { Referral Schemes; } \\
\text { Loyalty Programmes; } \\
\text { Social Media Campaigns; } \\
\text { Catchment Campaigns; } \\
\text { TV Commercials; } \\
\text { Celebrity Endorsements; } \\
\text { Banners and Hoardings; } \\
\text { Special Events. }\end{array}$ & $\begin{array}{l}\text { Brick-and-Mortar Retail Formats: } \\
\text { 1) EBO } \\
\text { 2) Brand SIS in MBO } \\
\text { a) Local Retailers } \\
\text { b) Regional Retailers } \\
\text { c) National Retailers } \\
\text { 3) Distributed to Small Retailers }\end{array}$ \\
\hline
\end{tabular}

Fig. 2: Existing Marketing Mix of Indian lifestyle brands.

$T V=$ Television $; E B O=$ Exclusive Brand Outlet; SIS = Shop-in-Shop; $M B O=$ Multi-Branded Outlet

The most important aspect of "4P's" framework is internal and external 'People', internal being the employees and external being the consumers and how these internal people 'employees' utilize the basic "4P's" of the Marketing Mix to ultimately influence the external people 'consumers' through processes. In the existing Marketing Mix this aspect was completely ignored. Most of the employees, employee roles, products, processes, performance indicators, promotions, communication tools, campaign contents, campaign methodologies, advertising techniques, product displays, control systems, retailing formats chosen, weightage allocated to different retailing formats, planning cycles and most importantly 'unit economics' were tuned with supply side of the brand rather than demand side. As a result, select Indian lifestyle brands, a) were failing to collect consumer data efficiently; b) were unable to retain majority of consumers; c) could not witness consistent growth in revenue and profit; d) never seen majority of EBO and SIS stores delivering profits across online and offline retailing formats; e) were unable to manage cash flow in efficient manner; f) had piled up huge inventory with much lower inventory turns than industry average; g) were carrying higher level of inventory cover; h) were unable to derive optimal organizational structure, number of sales personnel in a store, EBO store size, SIS size, store location, city type, discount level, category mix and most importantly) were failing to gain any strategic and competitive advantage over other lifestyle brands in the market.

5.2 Proposed Marketing Mix - Conceptual: We would like to define key concepts of the proposed Marketing Mix before we head to explain the effective execution of the framework.

Product (P1): First and foremost, the important aspect of Marketing Mix is 'Product'. Considering both supply and demand side attributes we have classified products into different groups in the proposed Marketing Mix. This grouping is based on numerous empirical and experimental research we have previously carried out and are relevant to Indian retailing context along with being helpful in getting all the stakeholders of the retail organization to focus on products / categories which are already proven to be capable of driving consumer repeat store visit frequency and thereby enhancing consumers intention to get associated with the brand on a longterm basis[95 to 99]. Essential (P1A): All the SKUs of the brand which are required by the consumers for frequent usage and are 'need to-have' category of consumers wardrobe. For example, Inner Wear, Sleep 
Wear, Home Wear, Active Wear, etc. Fashion (P1B): All the SKUs of the brand which are designed / developed based on the existing or forecasted market / fashion trend and are required by the consumers for lesser frequency of usage as compared to essential products and are 'want to-have' category of consumers wardrobe. For example, Celebrity inspired Kurta, Trend inspired Jeans, Social media inspired Handbag, Movie inspired Sunglass etc. Occasional (P1C): All the SKUs of the brand which are designed / developed for a specific occasion and are required by the consumers for almost one-time usage over a longer period of time and are 'demand to-have' category of consumers wardrobe. For example, Wedding Clothes, Party Dresses, Rain Wear, Trekking Shoes, Heavy Winter Jackets, etc.

Price (P2): Irrespective of the overall price positioning of the brand, it is imperative to follow the price lining strategy. As much as possible majority of product line offered to consumers by the brand must encompass price lining [76]. Based on this concept we have classified the 'price' aspect of the proposed Marketing Mix as low, mid, and high price points. Low-Price Points(M1): All the SKUs which are offered by the brand belonging to a particular product line bearing an average MRP (maximum retail price / objective price / original price) at least 50 percent lesser than the brand's overall price positioning for that particular product line. Mid-Price Points (M2): All the SKUs which are offered by the brand belonging to a particular product line bearing an average MRP equivalent to brand's overall price positioning for that particular product line. HighPrice Points (M3): All the SKUs which are offered by the brand belonging to a particular product line bearing an average MRP at least 50 percent higher than the brand's overall price positioning for that particular product line. For example, if the overall price positioning of the brand for Men's essential TShirt product line is INR 399 then the low-price points SKUs in the line must be priced at INR 199 on an average and high-price point SKUs to be priced at INR 599 on an average.

Promotion (P3): Promotion is one of the most important aspects in establishing a true lifestyle brand image in employees, investors, competitors and consumers mind and discounts / offers have become even more important post emergence of online store format in India as consumer perspective towards discount has changed [100]. We have classified promotions by discount type, discount method, discount level, scope of discount applicability / inventory coverage (P3A), store level (P3B) and brand level promotions (P3C) in the proposed Marketing Mix. These classifications are based on numerous empirical and experimental research we have previously carried out and are relevant to Indian retailing context [101 to 104]. Definition of few key elements of Promotion are; Centralized Promotions: All the offers, discounts, promotions designed, developed, and controlled by the central head office. Decentralized Promotions: All the offers, discounts, promotions designed, developed, and controlled by the store management team who have been administered by the central head office team through standard and well-defined upper limits. Customised Promotions: All the offers, discounts, promotions specifically designed and communicated to relevant group or individual consumers. Short-Term Promotions: All the offers, discounts, promotions run for a period of one to seven days. Long-Term Promotions: All the offers, discounts, promotions run for a minimum period of one month. All Stocks Promotions: All the offers, discounts, promotions when applied on all the SKUs available in the store. Old Stocks Promotions: All the offers, discounts, promotions when applied on select SKUs which are aged beyond 180 days in the central system. Specific Product Line / SKU Promotions: All the offers, discounts, promotions when applied on all the SKUs belonging to a specific product line or category of the brand. Repeat Consumer Recognition by the Sales Personnel: Standard programme created by the brand which enables Sales Personnel in the stores to identify and recognize consumers who have come back to the store so as to create positive perceptions about the brand in consumers mind. Sales Personnel as Brand Ambassadors: Standard programme created by the brand which enables Sales Personnel to enact themselves as brand ambassadors in the stores to create positive perceptions about the brand in consumers mind. Product-Market Penetration: A promotional technique wherein the brand will constantly attempt to place and list their products across different retailing formats and places relevant to brand's positioning within and outside the country 
to create wider 'awareness' about the brand with its target consumer group. Space-on-Hire: A promotional technique wherein the brand will constantly attempt to hire advertising places available within the store in which the brand is present across different retailing formats and places to create catchment specific 'familiarity' of the brand with its target consumer group both existing and potential in the store area. Catchment-Centric Advertisements: A promotional technique wherein the brand will constantly attempt to advertise outside the store in which the brand is present but within the store's catchment area across different retailing formats and places to create catchment specific 'awareness and familiarity' of the brand with its target consumer group both existing and potential in the catchment area.

Equal and high weightage to overall Brand performance related KPIs for all the Employees irrespective of their department/function added with systematic Empowerment of Sales Personnel and systematic Decentralization of control systems.

\begin{tabular}{|c|c|c|c|}
\hline $\begin{array}{c}\text { Product (P1) } \\
\text { (descending order of priority) }\end{array}$ & $\begin{array}{c}\text { Price (P2) } \\
\text { (descending order of priority) }\end{array}$ & $\begin{array}{c}\text { Promotion (P3) } \\
\text { (descending order of priority) }\end{array}$ & $\begin{array}{c}\text { Place (P4) } \\
\text { (descending order of priority) }\end{array}$ \\
\hline P1A. Essential & $\begin{array}{l}\text { P2A. Es sential: } \\
\text { P2AM2 - Mid-Price Points } \\
\text { P2AM1 - Low-Price Points } \\
\text { P2AM3 - High-Price Points }\end{array}$ & $\begin{array}{l}\text { P3A. Discounts: } \\
\text { P3AD1 - Decentralized; High Customization; } \\
\text { Long Term; All Stocks } \\
\text { P3AD2 - Centralized; High Customization; } \\
\text { Short Term; Old Stocks } \\
\text { P3AD3 - Centralized; High Customization; } \\
\text { Short Term; Specific SKU }\end{array}$ & $\begin{array}{l}\text { P4A. Essentials: } \\
\text { P4AL1 - MBO Local Retailer } \\
\text { P4AL2 - MBO Regional Retailer } \\
\text { P4AL3 - MBO National Retailer } \\
\text { P4AL4 - EBO Offline } \\
\text { P4AL5 - EBO Online } \\
\text { P4AL6 - MBO Speciality Online Retailer } \\
\text { P4AL7 - MBO Generalist Online Retailer }\end{array}$ \\
\hline P1B. Fashion & $\begin{array}{l}\text { P2B. Fashion: } \\
\text { P2BM2 - Mid-Price Points } \\
\text { P2BM3 - High-Price Points } \\
\text { P2BM1 - Low-Price Points }\end{array}$ & $\begin{array}{l}\text { P3B. Store Level Promotions: } \\
\text { P3BD1 - Centralized; Create excitement with } \\
\text { Updates on Upcoming Products and Range } \\
\text { of Products } \\
\text { P3BD2 - Centralized; Programmes on Repeat } \\
\text { Consumer Recognition by the Sales } \\
\text { Personnel } \\
\text { P3BD3 - Centralized; Programme on Sales } \\
\text { Personnel as Brand Ambassadors }\end{array}$ & $\begin{array}{l}\text { P4B. Fashion: } \\
\text { P4BL - MBO National Retailer } \\
\text { P4BL2 - MBO Regional Retailer } \\
\text { P4BL4 - EBO Offline } \\
\text { P4BL5 - EBO Online } \\
\text { P4BL6 - MBO Speciality Online Retailer } \\
\text { P4BL - MBO Local Retailer } \\
\text { P4BL7 - MBO Generalist Online Retailer }\end{array}$ \\
\hline P1C. Occasional & $\begin{array}{l}\text { P2C. Occasional: } \\
\text { P2CM3 - High-Price Points } \\
\text { P2CM2 - Mid-Price Points } \\
\text { P2CM1 - Low-Price Points }\end{array}$ & $\begin{array}{l}\text { P3C. Brand Level Promotions: } \\
\text { P3CD1 - Decentralized; 'Product-Market' } \\
\text { Penetration } \\
\text { P3CD2 - Decentralized; 'Space-on-Hire' at } \\
\text { SIS Stores } \\
\text { P3CD3 - Centralized; Catchment-Centric } \\
\text { Advertisements }\end{array}$ & $\begin{array}{l}\text { P4C. Occasional: } \\
\text { P4BL5 - EBO Online } \\
\text { P4BL4 - EBO Offline } \\
\text { P4BL6 - MBO Speciality Online Retailer } \\
\text { P4BL3 - MBO National Retailer } \\
\text { P4BL2 - MBO Regional Retailer } \\
\text { P4BL1 - MBO Local Retailer } \\
\text { P4BL7 - MBO Generalist Online Retailer }\end{array}$ \\
\hline \multicolumn{4}{|c|}{$\begin{array}{c}\text { Group C1: Baby (0-1 Year), Infant (1 to } 3 \text { Years), Pregnant Women and Nursing Women } \\
\text { Group C2: Kids (2 to } 8 \text { Years) } \\
\text { Group C3: Boys and Girls (8 to 16 Years) } \\
\text { Group C4: Young Women (18 to } 30 \text { Years) and Young Men (18 to } 30 \text { Years) } \\
\text { Group C5: Mid-Aged Women ( } 31 \text { to } 50 \text { Years) and Mid-Aged Men (31 to } 50 \text { Years) } \\
\text { Group C5: Old Women (Above } 50 \text { Years) and Old Men (Above } 50 \text { Years) }\end{array}$} \\
\hline
\end{tabular}

Fig. 3: Proposed Marketing Mix for a true lifestyle brand in India.

Place (P4): Type of place in which a brand has its presence is one of the key indicators of a brand's overall positioning in consumers, investors, and employees minds. Place also plays an important role in determining brand's profitability. We have classified place into different types in the proposed
Marketing Mix. These classifications are based on various empirical and experimental research we have previously carried and are relevant to the Indian retailing context [105 to 108].MBO Local Retailers (L1):These are Multi-Branded brick-and-mortar stores managed by retailers having their presence 
only in a particular city of India and allow lifestyle brands to showcase and sell their products through a shop-in-shop method (For example, Channabasappa \& Sons Davanagere, Karnataka). MBO Regional Retailers (L2): These are Multi-Branded brick-andmortar stores managed by retailers having their strong presence in specific regions of India and allow lifestyle brands to showcase and sell their products through a shop-in-shop method (For example, Kapsons Punjab). MBO National Retailers (L3): These are Multi-Branded brick-and-mortar stores managed by retailers having their presence all over India and allow lifestyle brands to showcase and sell their products through a shop-in-shop method (For example, Shoppers Stop). EBO Offline(L4): These are brick-and-mortar stores selling products belonging to the brand exclusively. EBO Online (L5): Online store selling products belonging to the brand exclusively MBO Speciality Online Retailers (L6): These are Multi-Branded online stores managed by retailers and focussed on specific categories of products and allow lifestyle brands to list and sell their products (For example, Myntra).MBO Generalist Online Retailers (L7): These are Multi-Branded online stores managed by retailers and mostly sell all the categories of products and allow lifestyle brands to list and sell their products (For example, Flipkart).

In addition to these basic "4P's" what is also important in the Marketing Mix is People both internal and external. During our exploratory phase of this research, we have noticed that all the lifestyle brands in the study were following department and function specific Key Result Areas (KRAs) and Key Performance Indicators (KPIs) for their employees and majority of the employees were not responsible for 'consumer retention rate' and 'overall brand profitability'. In the proposed Marketing Mix we have indicated that KRAs and KPIs of all the employees in the brand irrespective of their department and function need to be allotted with equal and major weightage for the overall brand performance and consumer retention rate. This helps all the employees Total Quantity Sold in Essential (Q1)

Total Quantity Sold in Fashion (Q2)

Total Quantity Sold in Occasional (Q3)

Total Quantity Sold (Q)

MRP Sale Value of Essential (S1)

MRP Sales Value of Fashion (S2) to focus on one simple goal and they shall possibly attempt to contribute to the overall brand performance and creating true lifestyle brand perception in consumers and investors mind. As far as the target consumer is concerned, while studying the select lifestyle brands as part of the qualitative research, it was observed that majority of lifestyle brands in India do not have 'focussed' consumer target group and even if they have they are failing to offer products across life-stage needs of their target consumers. They are neither exploiting the product category they are strong at and nor the target consumer target group they are already catering to through their strong product category. To address this typical issue, we have grouped target consumers into C1: Baby (0-1 Year), Infant (1 to 3 Years), Pregnant Women and Nursing Women. C2: Kids (2 to 8 Years); C3: Boys and Girls (8 to 16 Years); C4: Young Women (18 to 30 Years) and Young Men (18 to 30 Years); C5: MidAged Women (31 to 50 Years) and Mid-Aged Men (31 to 50 Years); C5: Old Women (Above 50 Years) and Old Men (Above 50 Years). Lifestyle brands need to be cognizant of the universally proven fact that consumer's needs significantly change based on their age and always take this phenomenon in to consideration while choosing their target consumers in relation to the product category they offer.

5.3 Proposed Marketing Mix- Mathematical: After key concepts being defined in relation to proposed Marketing Mix for a true lifestyle brand, we would now head on to elaborate the proposition. In the proposed Marketing Mix framework as shown in Figure 3, one can observe that all the "4P's" has been allocated with a vast list of sub elements grouped based on demand side attributes along with recommended priorities which are expected to be the overall revenue, profitability and image mix of the brand. Let us understand the mathematical structure of deriving the overall brand profitability and the impact of prioritization of each sub elements on consumer repeat behaviour as detailed below in the order of starting point to ending point.

$=\sum$ (Quantity Sold in P1A)

$=\sum$ (Quantity Sold in P1B $)$

$=\sum$ (Quantity Sold in P1C)

$=\sum(Q 1, Q 2, Q 3)$

$=(\mathrm{P} 1 \mathrm{~A} X \mathrm{P} 2 \mathrm{~A})$

$=(\mathrm{P} 1 \mathrm{~B} \times \mathrm{P} 2 \mathrm{~B})$ 
MRP Sales Value of Occasional (S3)

Total MRP Sales Value (S)

Gross Sale Value of Essential (G1)

Gross Sales Value of Fashion (G2)

Gross Sales Value of Occasional (G3)

Total Gross Sales Value (G)

Earning Value of Essential (E1)

Earning Value of Fashion (E2)

Earning Value of Occasional (E3)

Total Gross Sales Value (E)

Expenses of MBO Local Retailing(L1)

Expenses of MBO Regional Retailing (L2)

Expenses**)

Expenses of MBO National Retailing (L3)

Expenses**)

Expenses of EBO Offline Stores (L4)

Expenses of EBO Online Store (L5)

Expenses of MBO Speciality Online Retailing (L6)

Expenses*****)

Expenses of MBO Generalist Online Retailing (L7)

Expenses $* * * * *)$

Total Store Expenses (L)

Overall Brand Profit/Loss (BP)

* Cost of Goods Sold

** Brand Employee Cost; Central Sales Organization Employees Allocated Cost; Logistics Cost; Mother/Feeder Warehouse Cost Allocated to Store; Inventory Carrying Cost.

*** Direct Store Costs such as, Logistics Cost; Employee Cost; Central Sales Organization Employees Allocated Cost; House Keeping Expenses; Security Personnel Cost; Power and Fuel Cost; Credit Card Charges; Debit Card Charges; Home Delivery Expenses; Repair Cost; Store Consumables Cost; Uniform Expenses; Clothing Alteration Expenses; Legal Fee; Professional Fee; Inventory Insurance Cost; Store Employees Welfare Expenses; Back-Store Office Maintenance Cost; Mother/Feeder Warehouse Cost Allocated to Store; Inventory Carrying Cost; Promotional Expenses Allocated to Store.

**** Digital Cataloguing Cost; Digital Promotions Cost; Logistics Cost; Delivery Cost; Product Returns Cost; Mother/Feeder Warehouse Cost Allocated to Store; Inventory Carrying Cost.

***** Digital Cataloguing Cost; Digital Promotions Cost; Logistics Cost; Delivery Cost; Product Returns Cost; Mother/Feeder Warehouse Cost Allocated to Store; Inventory Carrying Cost.

The mathematical structure clearly demonstrates that overall brand profitability is directly proportional to product group mix, price lining mix, promotion mix

and the type of place the brand is located and if skewed predominantly towards the priority proposed in the new Marketing Mix could possibly lead to higher consumer repeat visits and consumer retention thereby increasing the probability of establishing a true lifestyle brand in employees, investors and consumers mind. The road to brand profitability and true lifestyle brand image establishment journey, in fact, is full of mathematically derived numbers which are mostly 'output' in nature, the only one number that influences all these outputs and derived numbers is the total number of invoices / bills being generated by the brand's sales personnel and most importantly the product group composition of the majority of these invoices / bills. If the majority of bills are composed of products which have explicit capability to drive consumers' repeat purchase behaviour, repeat 
store visit frequency and in turn, the retention rate would be detrimental in establishing a true lifestyle brand image. Thus, the grouping of each sub elements of "4P's" clubbed with priority matrix mix within among "4P's" which have been designed as part of the proposed Marketing Mix plays an important role in deriving the strength of the proposed model [109]. The grouping and prioritization are the key changes cum rationalization being proposed to the existing Marketing Mix. The Schematic representation of this journey is presented in Figure 4. One can clearly see that every milestone in the journey to final brand profitability is important, but at the same time, it is imperative for lifestyle brands to understand the difference among input, output, fixed, variable, and derived milestones of this journey. Our proposed Marketing Mix, has deliberately considered the role of each of these components while designing the new. proposition and significantly gives importance to 'input' variables.

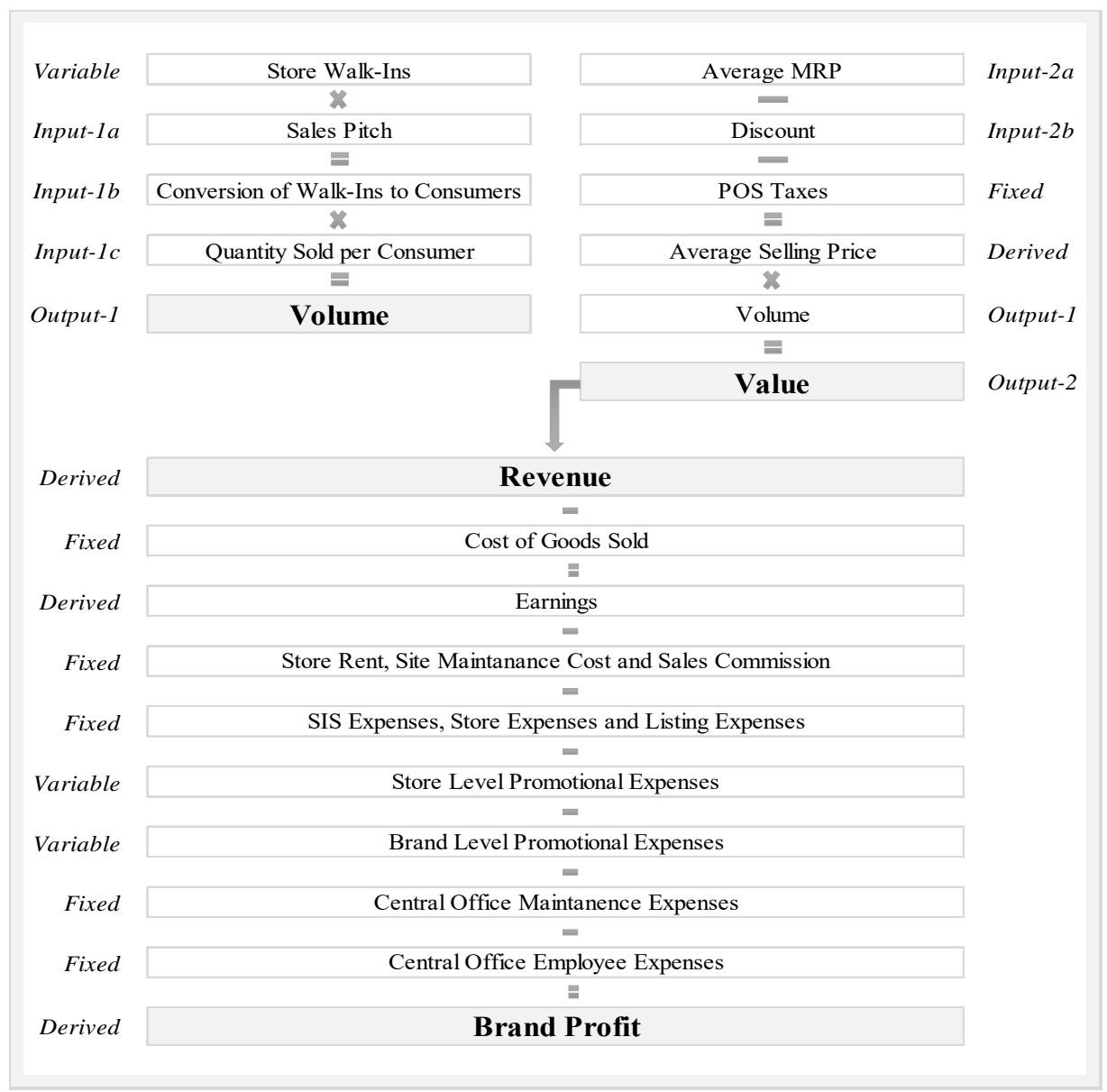

Fig. 4: Schematic presentation of road to brand profit.

\section{EXECUTIONOFPROPOSED MARKETING MIX :}

We are cognizant of the fact and it is inevitable that the magnitude of changes and rationalizations proposed to the existing Marketing Mix shall need significant attitudinal changes across all employees of the brand starting from the 'Chief Executive Officer' to the 'Sales Personnel'. Thus, we have outlined key recommendations on the wholistic execution of the proposed Marketing Mix to increase the probability of the success of the proposed model. It is inevitable that to achieve the true lifestyle brand image, brand organization must attempt to incorporate these 
recommendations together and across. The proposed Marketing Mix shall not be effective and efficient if the brand organization attempts to change their existing Marketing Mix in phases or steps or in silos. 6.1 Supply Side: As mentioned earlier there are more than 5000 Indian lifestyle brands in addition to wellknown global lifestyle brands in India. It is universally accepted phenomenon that the 'Product' plays an important role in establishing a 'true lifestyle brand' image in consumers mind and it is imperative to all the lifestyle brands that, each product tagged with the brand name must be created in such a way it creates positive perceptions and long term memories in the consumers mind. Figure 5 indicates different ways through which a lifestyle brand can create a unique supply side proposition and use them as key inputs for brand level promotions (P3C).

\begin{tabular}{|c|c|c|}
\hline \multicolumn{3}{|c|}{ Supply Side } \\
\hline Key Focus Area & Key Working Area & Key Goal \\
\hline $\begin{array}{l}\text { Create / Own wider } \\
\text { Unique Brand } \\
\text { Properties }\end{array}$ & $\begin{array}{l}\text { Raw Material Components } \\
\text { Trims } \\
\text { Fits } \\
\text { Silhouettes } \\
\text { Testing Standards } \\
\text { Finishes } \\
\text { Packaging }\end{array}$ & $\begin{array}{l}\text { i) Own and use these unique properties to promote the brand. } \\
\text { ii) Use them as strong communication contents. } \\
\text { iii) Each product to be a rational combination of these properties } \\
\text { to ensure optimal total product cost. }\end{array}$ \\
\hline $\begin{array}{l}\text { Build / Nominate } \\
\text { wider Supply Side } \\
\text { Partners }\end{array}$ & $\begin{array}{l}\text { Designers } \\
\text { Raw Material Components } \\
\text { Trims } \\
\text { Finishes } \\
\text { Testing } \\
\text { Packaging } \\
\text { Product Assembly } \\
\text { Logistics } \\
\text { Warehousing }\end{array}$ & $\begin{array}{l}\text { i) Use specialists in each area of supply. } \\
\text { ii) No single product to be a creation of single partner vendor } \\
\text { partner. } \\
\text { iii) Costs rationalization. } \\
\text { iv) Make it hard to reproduce a product by any competitor. }\end{array}$ \\
\hline
\end{tabular}

Fig.5: Recommended supply side proposition.

6.2 Demand Side: In the proposed Marketing Mix we have prioritized Product-Market penetration over advertising activities. We believe that Lavidge and Steiner's original 'hierarchy of effects model' conceptualized during 1960's, the consumer's journey of purchase decision begins with 'Awareness' [94]. 'Awareness combined with Familiarity' should be given priority in the beginning stages of establishing a true lifestyle brand. Consumer retention rate or consumer loyalty are output in nature whereas 'Awareness' is an input component of consumer purchase decision making process. We have captured some of the key working areas in Figure 6 which paves a path in achieving the main goal of connecting the brand with both existing and potential target consumers and indicates different ways through which a lifestyle brand can create unique demand side proposition in addition to using them as key inputs for brand level promotions (P3C). 


\section{Demand Side}

\begin{tabular}{|c|c|c|}
\hline Key Focus Area & Key Working Area & Key Goal \\
\hline $\begin{array}{l}\text { Create, Own and } \\
\text { Service wider } \\
\text { Target Group of } \\
\text { Consumers }\end{array}$ & $\begin{array}{l}\text { Boys and Men } \\
\text { Girls and Women } \\
\text { Babies and Infants } \\
\text { Kids } \\
\text { Apparel } \\
\text { Foot Wear } \\
\text { Accessories } \\
\text { Price Lining }\end{array}$ & $\begin{array}{l}\text { i) Cater to wider target consumer groups with specific product } \\
\text { categories or wider product categories for specific target group of } \\
\text { consumers. } \\
\text { ii) Maximize reach \& conversion of any communication efforts. } \\
\text { iii) Minimum cannibalization \& maximum basket size. } \\
\text { iv) Create 'Go-To' brand perception for any life-stage need. }\end{array}$ \\
\hline $\begin{array}{l}\text { Collaborate with } \\
\text { wider Retailing } \\
\text { Partners }\end{array}$ & $\begin{array}{l}\text { Off-Line Retailers } \\
\text { On-Line Retailers } \\
\text { Multi Branded Retailer } \\
\text { Exclusive Brand Outlets } \\
\text { Generalist Retailers } \\
\text { Specialist Retailers } \\
\text { National Retailers } \\
\text { Regional Retailers } \\
\text { Local Retailers } \\
\text { Distributors } \\
\text { Aggregators }\end{array}$ & $\begin{array}{l}\text { i) Utilize expertise of specialists in each area of demand generation. } \\
\text { ii) Have specific roles defined for every demand generating partner. } \\
\text { iii) Consider part of the partnering costs as part of brand-level } \\
\text { promotional costs to understand true impact on retail format level } \\
\text { profitability. } \\
\text { iv) Take the brand where the customer is already shopping and ease } \\
\text { customer shopping efforts by making it available across existing } \\
\text { purchase options for them. } \\
\text { vi) Create brand awareness through Product-Market penetration and } \\
\text { let customers get familiar with the brand. }\end{array}$ \\
\hline
\end{tabular}

Fig. 6: Recommended demand side proposition.

\begin{tabular}{|c|c|c|}
\hline \multicolumn{3}{|c|}{ Connecting Supply and Demand Side } \\
\hline Key Focus Area & Key Working Area & Key Goal \\
\hline $\begin{array}{l}\text { People and } \\
\text { Process }\end{array}$ & $\begin{array}{l}\text { Organization Structure } \\
\text { Functional Experts } \\
\text { InculcateBrand Attitude through Training } \\
\text { Build Processes and Systems } \\
\text { Minimum Manual Interventions } \\
\end{array}$ & $\begin{array}{l}\text { i) Employees-Business Model-Fit. } \\
\text { ii) Ownership of each functions with measurable deliverables. } \\
\text { iii) Strengthen processes over people. }\end{array}$ \\
\hline Technology & $\begin{array}{l}\text { Connect Products } \\
\text { Connect Partners } \\
\text { Connect Employees } \\
\text { Connect Customers } \\
\text { Data Analytics } \\
\text { Data Science }\end{array}$ & $\begin{array}{l}\text { i) Seamless interface of products, processes, partners and } \\
\text { consumers. } \\
\text { ii) Enable technology to provide key insights on performance } \\
\text { across people, product, processes, partners and consumers. }\end{array}$ \\
\hline Communication & $\begin{array}{l}\text { Internal Updates } \\
\text { Product Benefits } \\
\text { Utility of Product } \\
\text { Create Awareness } \\
\text { Need Based Content } \\
\text { Solution Based Campaigns } \\
\text { Sales Personnel as Brand Ambassadors } \\
\text { Patriciate Fashion Events } \\
\text { Create Brand Community Clubs } \\
\text { Reward Influencers } \\
\text { Digital Connect }\end{array}$ & $\begin{array}{l}\text { i) Employee to first know the happenings in the brand across } \\
\text { functions. } \\
\text { ii) Creating awareness on relevance of each product for a } \\
\text { specific life-stage need. } \\
\text { iii) Keep a 'constant' touch with new and existing customers } \\
\text { with 'consistent' communication contents. } \\
\text { iv) Create excitement in customer's mind with updates on } \\
\text { upcoming products / promotions / events. }\end{array}$ \\
\hline
\end{tabular}

Fig. 7: Recommended framework for connecting supply and demand side. 
6.3 Connecting Supply and Demand Side: What is most important in achieving the goal of establishing a true lifestyle brand image is the way in which a brand connects the supply side with the demand side attributes. Figure 7 gives a ready framework for brands to understand major focus and working areas using which they could possibly connect supply and demand side attributes seamlessly.

The model proposed in the new Marketing Mix which basically gives utmost importance to input variables across all the "4P's" such as a) P1-Sales Pitch; b) P2-Product's Original Price (MRP); c) P3-Discount Methodology and; d) P4-Brand Placement, demonstrates a significantly positive association between prioritization level of key input variables and brand's profitability significantly moderated by overall consumer repeatability [109].

\section{DISCUSSION AND CONCLUSION :}

Through this intensive research work, we have noticed that it is not just about identifying the ideal category, product, price level, discount level, advertising technique, brand location, SIS / store size, supply partners, demand generation partners and sales personnel, it is all about the right mixture of all these elements in relation to target consumers and overall business goal of the brand and the positioning the brand aims to take in the consumers mind. It is also not about achieving the ideal mixture for a few of these elements in silos, what is imperative and inevitable is the overall mixture of all these elements / sub elements and not just one or two. Another important fact we have found in this research is, Indian lifestyle brands need to relook at some of the strong beliefs they and their employees carry and test them with real-time facts, data and continuous unbiased observations, otherwise, it would furthermore add-on to the existing complexity of establishing a true lifestyle brand image. Marketing Mix is the most important and basic pillar of lifestyle brands irrespective of products they offer, price positioning they maintain, promotion tactics they adopt and retailing formats through which they sell their products unless one has this mixture in right proportion across all the "4P's" it is difficult to build a sustainable and true lifestyle brand in India.
We have also noticed that majority of Indian lifestyle brands are spending most of their time in inventing new "P's" to be added to the basic "4P's" proposition rather than working on existing " $4 \mathrm{P}$ 's" and rationalizing them to suit consumer expectations. In one of our previous researches wherein, we experimented a re-prioritized and rationalized "4P's" framework had shown that about 70 percent of the 'store level' profitability could be determined by just working on the basic "4P's" [109].

\section{SUGGESTIONS TO INDIAN LIFESTYLE BRANDS :}

Before we start writing suggestions, let us look at an example of a typical Indian lifestyle brand organization's attitude. A lifestyle brand organization might believe that their biggest strength is in making Sleep Wear Apparel for MidAged Women, they believe that they understand the category better than competitors. It is not at all wrong in focussing on specific product line or category, but at the same time what is very important is to ask yourselves as to what stops your brand to extend the offering to few more consumer groups using the same product line or category?. On the other hand, a lifestyle brand might believe that their biggest strength is in understanding a specific consumer group for example Kids, they believe that they understand Kids consumer group better than competitors. It is not at all wrong in focussing on a specific consumer group, but at the same time what stops you to extend your product line and categories to cater to the majority of the life-stage needs of your focussed consumer group Kids?. Both developing and developed Indian lifestyle brands need to identify every other lifestyle brand's key business goal and their target consumer group which could have compelled them to have a particular Marketing Mix whether they are organized, semi-organized or unorganized. Sustainable success of a lifestyle brand significantly depends on the level of trueness the lifestyle brand carries in consumers mind and not the revenue or profit a brand generates. To ensure a brand gets true lifestyle image in the consumers mind, brands need to think beyond revenue and profit which is what has to be the main criteria while designing an ideal Marketing Mix. Be 
cognizant of the fact that, few brands may be trying to capture the bigger market share by just focussing on increasing the revenue; few brands may be trying to show exponential growth in their revenue to attract more investors; few brands may be assuming that consumers acquired based on discounts and advertising tactics as their key components of selling proposition are going to be loyal to their brand forever; few brands may be trying to create different perceptions in the consumers mind over their brand image, few brands may be opening many EBO stores in premium locations with larger size to tag them as experiential, anchor or destination stores assuming that this effort would lead them to create a premium brand image in consumers, competitors and investors mind; few brands may be expanding their presence in catchment areas irrespective of their target consumer groups to promote their brand to attract new investors, franchisees and licensees; few conglomerates may be trying to show their presence in the lifestyle brand segment to strengthen their group portfolio; few may be selling premium priced products or categories to position themselves as premium lifestyle brands and so on. What is very important is the key business goal of your brand, your target consumer group, target consumer group's attitude towards your Marketing Mix and most importantly your aim to establish a true lifestyle brand image in employees, investors, competitors, and consumers mind. Lifestyle brand organizations must be aware that the perspective towards the existing Marketing Mix might not be same among your employees, investors, competitors and consumers, and one achieves a true lifestyle brand image only when majority of internal and external stakeholder's perspectives / perceptions are same and positive towards the brand. Finally, we would like to bring to Indian lifestyle brand organizations attention that, any modifications whether small or big in magnitude to their existing Marketing Mix shall not be a short term exercise and shall not yield favourable results without allowing the modifications in the Marketing Mix to settle over a period of time and in addition what is of utmost importance is the level of acceptance and adaptation among all the stakeholders of the brand organization. To ensure higher level of acceptance and adaptation across the brand organization, brands in addition to modifying Marketing Mix must also always modify the KRAs and KPIs of all the stakeholders in relation to expected outcomes of the modifications in the Marketing Mix.

\section{LIMITATIONS OF RESEARCH :}

The main limitation of this research work is the coverage of various stakeholders viz., number of lifestyle brands, product categories, consumer groups, employees, price positioning, product mix, category mix and different types of Marketing Mix in designing the new framework. This might limit the generalizability of research findings to other set of lifestyle brands. The second limitation would be the empirical validation is restricted to few Indian lifestyle brands selected for the study and hence the generalizability of the findings and suggestions to other Indian lifestyle brands. The third limitation would be our ability to carry out an experiment, though we were firm in our approach that, the proposed Marketing Mix has to be tested in the field before we recommend, it was not that easy merely because of the vast scope of the experiment. Unlike other experiments wherein the treatment is limited to few concepts, components or variables this experiment in fact required us to cover practically almost all the elements of the Marketing Mix which do require longer duration for preparations prior to testing, longer duration prior to the beginning of extracting the results and longer period of time for the experimentation itself to ensure findings and insights are derived holistically. At best we were able to elaborate the key steps required in executing the proposed Marketing Mix based on our research findings of similar experiments on implementing a new Marketing Mix framework [109] and we shall in some time implement the proposed Marketing Mix with a select Indian lifestyle brand and publish the results. However, as the proposed Marketing Mix is being designed based on previous empirical and experimental research findings [95 to 109], it provides significant input regarding the ways in which Indian lifestyle brands could utilise this new proposition to start their journey towards becoming a 'true lifestyle brand'.

\section{SCOPE FOR FURTHER RESEARCH :}

We strongly recommend that the proposed 
Marketing Mix is experimented by researchers and the same is fine tuned further if required for the Indian lifestyle or non-lifestyle brands. Based on the key business objectives and their target consumer group, Indian lifestyle brands can implement the proposed Marketing Mix on a pilot basis and fine tune the same based on real-time findings which can then be implemented on a permanent basis.

\section{REFERENCES :}

[1] Schmitt, B (2012). The consumer psychology of brands. Journal of Consumer Psychology, 22(1), 7-17. doi:10.1016/j.jcps.2011.09.005.

[2] http://www.technopak.com/Files/fashionretail-scenario-in-india.pdf. Retrieved in June 2020.

[3] http://statisticstimes.com/demographics/popu lation-of-india.php. Retrieved in June 2020.

[4] https://www.mckinsey.com/industries/retail/o ur-insights/the-state-of-fashion-2019-a-year-ofawakening. Retrieved on $05^{\text {th }}$ June 2020.

[5] https://www.amazon.in/b/?ie=UTF8\&node $=6$ 648217031\&ref_=topnav_storetab top_ap_mega.

Retrieved in June 2020.

[6] Borden, N. H. (1965). The Concept of the Marketing Mix. G. Schwartz, Science in Marketing, (pp. 386-397). New York: John Wiley $\&$ Sons.

[7] McCarthy, E. J. (1960). Basic Marketing: A Managerial Approach. Homewood (Illinois): Richard D. Irwin.

[8] Möller, K. (2006). The Marketing Mix Revisited: Towards the 21st Century Marketing by E. Constantinides. Journal of Marketing Management, 22(3), 439-450.

[9] Popovic, D. (2006). Modelling the Marketing of High-Tech Start-Ups. Journal of Targeting, Measurement and Analysis for Marketing, 14(3), 260-276.

[10] Gummesson, E. (1994). Making Relationship Marketing Operational. International Journal of Service Industry Management, 5(5), 5-20.
[11] Sriram, V. and Sapienza, H. J. (1991). An empirical investigation of the role of marketing for small exporters. Journal of Small Business Management, 29(4), 33-43.

[12]Kotler, P. (1984). Marketing Management: Analysis, Planning and Control (5th ed.). New Jersey: Prentice-Hall.

[13] Ohmae, K. (1982). The Mind of the Strategist: The Art of Japanese Business. New York: McGrow-Hill Inc.

[14]Robins, F. (1991). Four Ps or Four Cs or Four Ps and Four Cs. Paper Presented at MEG Conference.

[15] Vignali, C. \& Davies, B. J. (1994). The Marketing Mix Redefined and Mapped Introducing the MIXMAP Model. Management Decision, 32(8), 11-16.

[16] Doyle, P. (1994). Marketing Management and Strategy. Prentice Hall.

[17]Bennett, A. R. (1997). The Five Vs - A Buyer's Perspective of the Marketing Mix. Marketing Intelligence \& Planning, 15(3), 151156.

[18] Yudelson, J. (1999). Adapting McCarthy's Four P's for the Twenty-First Century. Journal of Marketing Education, 21(1), 60.

[19] Schultz, D. E. (2001). Marketers: Bid Farewell to Strategy Based on Old 4Ps. Marketing News, 35(2), 7.

[20]Lauterborn, B. (1990). New Marketing Litany: Four Ps Passé: C-Words Take Over. Advertising Age, 61(41), 26.

[21]Rosenberg, L. \& Czepiel, J. (1992). A Marketing Approach to Consumer Retention. Journal of Consumer Marketing, 59, 58-70.

[22] Gummesson, E. (1997). Relationship Marketing as a Paradigm Shift: Some Conclusions From the 30R Approach. Management Decision, 35(4), 267-272.

[23] Grönroos, C. (1994). From Marketing Mix to Relationship Marketing: Towards A Paradigm Shift in Marketing. Management Decision, 32(2), 4-20. 
[24] Goldsmith R. E. (1999). The Personalized Marketplace: Beyond the 4Ps. Marketing Intelligence and Planning, 17(4), 178-185.

[25]Patterson, G.P. \& Ward, T. (2000). Relationship Marketing and Management Handbook Services Marketing and Management. Sage Publications Inc, 416.

[26] Healy, M., Hastings, K., Brown, L. \& Gardiner, M. (2001). The Old, The New and the Complicated - A Trilogy of Marketing Relationships. European Journal of Marketing, 35(1/2), 182-193.

[27]Booms B. H. \& Bitner B. J. (1980). Marketing strategies and organisation structures for service firms. In Donnelly, J. \& George W. R. (Eds.), Marketing of services, American Marketing Association, 47-51.

[28] Cowell, D. W. (1984). The Marketing of Services, Institute of Marketing and the CAM foundation, Heineman Professional Publishing.

[29] Brunner, G. C. (1989). The Marketing Mix: Time for Reconceptualization. Journal of Marketing Education, 11, 72-77.

[30] Rushton, A. \& Carson, D. J. (1989). Services - Marketing with A Difference? Marketing Intelligence and Planning, 7(5/6), 12-17.

[31]Fryar, C. R. (1991). What's Different About Services Marketing? The Journal of Marketing Services, 5(4), 53-58.

[32] Heuvel, J. (1993). Diensten Marketing (Services marketing). The Netherlands WoltersNoordhoff Groningen.

[33] Doyle, P. (1994). Marketing Management and Strategy. Prentice Hall.

[34] Melewar, T. C. \& Saunders, J. (2000). Global Corporate Visual Identity Systems: Using an Extended Marketing Mix. European Journal of Marketing, 34(5/6), 538-550.

[35]English, J. (2000). The Four "P"s of Marketing are Dead. Marketing Health Services, 20(2), 20-23.

[36] Grove, S.J., Fisk, R.P. \& John, J. (2000). Service as Theater, Guidelines and Implications,
Handbook Services Marketing and Management. Sage Publications Inc, 25.

[37]Beckwith, H. (2001). The Invisible Touch The Four Keys of Modern Marketing. Texere Publishing.

[38]Ster, V. D. W. (1993). Marketing En Detailhandel (Marketing and Retailing). The Netherlands: Groningen, Wolters-Noordhoff, 328.

[39]Boekema, J. J., Bueren Van, E. B, Lobstein, S., Oosterhuis, A. \& Schweitzer, P. (1995). Basisboek Marketing (Basic Book of Marketing), NL: Derdedruk, Groningen, Wolters-Noordhoff.

[40] Mulhern, F. J. (1997). Retail Marketing: From Distribution to Integration. International Journal of Research in Marketing,14(2), 103-124.

[41]Wang, F., Head, M. \& Archer, N. (2000). A Relationship-Building Model for The Web Retail Marketplace. Internet Research: Electronic Networking Applications and Policy, 10(5), 374384.

[42]Kotler, P. (2003). Marketing Management (11th ed.). Prentice Hall International Editions.

[43] Turnbull P., Ford, D. \& Cunningham, M. (1996). Interaction, Relationships and Networks in Business Markets: An Evolving Perspective. Journal of Business \& Industrial Marketing, 11(3/4), 44-62.

[44]Davis W. \& Brush, K. E. (1997). High-Tech Industry Marketing: The Elements of a Sophisticated Global Strategy. Industrial Marketing Management, 26(1), 1-13.

[45] Parasuraman, A. (1998). Customer Service in Business-to-Business Markets: An Agenda for Research. The Journal of Business and Industrial Marketing, 13(4), 309-321.

[46] Andersen, J. C. \& Narus J. A. (1999). Business Market Management, Understanding, Creating and Delivering Value. New Jersey. Prentice Hall.

[47]Peattie, K. (1997). The Marketing Mix in the Third Age of Computing. Marketing Intelligence \& Planning, 15(3), 142-150. 
[48] Aldridge, A., Forcht, K. \& Pierson, J. (1997). Get Linked or Get Lost: Marketing Strategy for the Internet. Internet Research: Electronic Networking Applications and Policy, 7(3), 161-169.

[49] Mosley-Matchett, J. D. (1997). Include the Internet in Marketing Mix. Marketing News, $31(25)$.

[50]Evans, J. R. \& King, V. E. (1999). Businessto-Business Marketing and the World Wide Web: Planning, Managing and Assessing Web Sites. Industrial Marketing Management, 28(4), 343358.

[51]Chaffey, D., Mayer, R., Johnston, K. \& EllisChadwick, F. (2000). Internet Marketing, Strategy, Implementation and Practice. FT/Prentice Hall, 40-48, 151-168.

[52]Lawrence, E., Corbitt, B, Fisher, J.A, Lawrence, J. \& Tidwell, A. (2000). Internet Commerce (2nd ed.). John Wiley \& Sons Australia Ltd, 79.

[53] O’Connor, J. \& Galvin, E. (1997). Marketing and Information Technology - The strategy, Application and Implementation of IT in Marketing. London: Pitman Publishing.

[54]Constantinides, E. (2002). The 4S WebMarketing Mix Model. Electronic Commerce Research and Applications,1(1), 57-76.

[55]James L. Heskett, W. Earl Sasser, Leonard Schlesinger (1997). The Service Profit Chain: How Leading Companies Link Profit and Growth to Loyalty, Satisfaction, and Value. New York: The Free Press.

[56]Lindquist, J.D. (1974). Meaning of Image: A Survey of Empirical and Hypothetical Evidence. Journal of Retailing,50(4), 29-38.

[57]Hirschman, E.C., Greenberg, B.\& Robertson, D. (1978). The intermarket reliability of retail image research: an empirical examination. Journal of Retailing,54(1), 3-12.

[58]Davis, H. L., \& Silk, A. J. (1972). Interaction and influence processes in personal selling. Sloan Management Review, 13(2), 59-69.
[59]Dawson, Lyndon E. Jr, Soper, B., \& Pettijohn, C. E. (1992). The effects of empathy on sales person effectiveness. Psychology \& Marketing, (1986-1998), 9(4), 297-310.

[60]Sharma, A. (2001). Consumer decisionmaking, salespeople's adaptive selling and retail performance. Journal of Business Research, 54(2), 125-129.

[61]Pettijohn, C. E., Pettijohn, L. S., \& Taylor, A. J. (2002). The influence of salesperson skill, motivation, and training on the practice of customer-oriented selling. Psychology \& Marketing, 19(9), 743-757.

[62]Davis, D. D. (2008). The influence of salesperson leadership as a customer interaction behavior on sales performance. Nova Southeastern University.

[63] Singh, S., Marinova, D., Singh, J., \& Evans, K. R. (2018). Customer query handling in sales interactions. Journal of the Academy of Marketing Science,46(5), 837-856.

[64]Gillis, C., Pitt, L., Robson, M. J., \& Berthon, P. (1998). Communication in the salesperson/customer dyad: An empirical investigation. Marketing Intelligence \& Planning, 16(2), 100-106.

[65] Singh, R., \& Venugopal, P. (2015). The impact of salesperson customer orientation on sales performance via mediating mechanism. The Journal of Business \& Industrial Marketing, 30(5), 594-607.

[66]Chen, Y., Rivas, A. A., \& Wu, W. (2018). Exploring the determinants and consequences of salesperson market orientation behavior. Journal of Service Theory and Practice, 28(2), 170-195.

[67]Weitz, Barton A. (1979). A Critical Review of Personal Selling Research: The Need for Contingency Approaches. Critical Issues in Sales Management: State-of-the-Art and Future Research Needs. Gerald Albaum and Gilbert A. Churchill, Jr. Eds. Eugene: College of Business Administration, University of Oregon, 76-126.

[68] Saxe, Robert, and Barton A. Weitz (1982). The SOCO Scale: A Measure of the Customer 
Orientation of Sales people. Journal of Marketing Research, 19 (3), 343-351.

[69]Brown T.J., Mowen, J.C. Donavan, D.T., and Licata, J.W. (2002). The Customer Orientation of Service Workers: Personality Trait Effects on Self- and Supervisor Performance Ratings. Journal of Marketing Research, 34(2), $110-9$.

[70]Vandewalle, Donald, Steven P. Brown, William L. Cron, and John W. Slocum (1999). The Influence of Goal Orientation and SelfRegulation Tactics on Sales Performance: A Longitudinal Field Test. Journal of Applied Psychology, 84 (2), 249-259.

[71]Liljenwall, R. (ed.) (2004). The Power of Point-of-Purchase Advertising: Marketing at Retail. Washington, DC: Point-of-Purchase Advertising International (POPAI).

[72]Nystrom, Harry (1970). Retail Pricing: An Integrated Economic and Psychological Approach. Stockholm: EFI.

[73]Hoch, S. J., Kim, B.-D., Montgomery, A. L. and Rossi, P. E. (1995). Determinants of storelevel price elasticity. Journal of Marketing Research, 32, 17-30.

[74]Desai, Kalpesh K., and Debabrata Talukdar (2003). Relationship Between Product Groups' Price Perceptions, Shopper's Basket Size, and Grocery Store's Overall Store Price Image. Psychology and Marketing, 20 (10), 903-933.

[75] Stole, L. A. (2007). Price Discrimination and Competition. in "Handbooks in Economics", ed. by M. Armstrong, and R. Porter, vol. 3 of Handbook of Industrial Organization, pp. 2221 2299. Elsevier.

[76]Levy, M., Weitz, B.A., and Beitelspacher, L.S., (2012). Retailing Management. ( ${ }^{\text {th }}$ Edition), McGraw Hill, Irwin.

[77] Salmon, W. J. (1989). Retailing in the age of execution. Journal of Retailing, 65(3), 368-378.

[78] Monroe, K. B., \& Guiltinan, J. P. (1975). A path-analytic exploration of retail patronage influences. Journal of Consumer Research, 2(1), 19- 28.
[79]Arnold, S. J., Oum, T. H., \& Tigert, D. J. (1983). Determinant attributes in retail patronage: Seasonal temporal, regional and international comparisons. Journal of Marketing Research, 20(2), 149-157.

[80]Mason, J. B., Durand, R. M., and Taylor, J. L. (1983). Retail patronage: A causal analysis of antecedent factors. In W. Darden, \& R. Lusch (Eds.), Patronage behavior and retail management (pp. 339-352). New York: NorthHolland.

[81]Keng, K. A., \& Ehrenberg, A. S. C. (1984). Patterns of store choice. Journal of Marketing Research, 21(4), 399-409.

[82]Louviere, J. J., \& Gaeth, G. J. (1987). Decomposing the determinants of retail facility choice using the method of hierarchical and international comparisons. Journal of Marketing Research, 63(1), 149-157. 942.

[83] Spiggle, S., \& Sewall, M. A. (1987). A choice set model of retail selection. Journal of Marketing, 51(2), 97-111.

[84]Dawson, S., Bloch, P. H., \& Ridway, N. M. (1990). Shopping motives, emotional states and retail outcomes. Journal of Retailing, 66(4), 408 427.

[85]Burke, R., Bari, R., Harlam, A., Kahn, B. E., \& Lodish, L. M. (1992). Comparing dynamic consumer choice in real and computer- simulated environments. Journal of Consumer Research, 19(1), 71-82.

[86] https://www2.deloitte.com/content/dam/Delo itte/in/Documents/consumer-business/inconsumer-RLS-2019-noexp.pdf. Retrieved in June 2020 .

[87] Biel, A. (1993). Converting image into equity. In 'Brand Equity and Advertising', Aaker, D. and Biel, A. (eds), Lawrence Erlbaum Associates, Hillsdale, NJ, pp.67-82.

[88] Michel Laroche and Robert Sadokierski (1994). Role of confidence in a multi-brand model of intentions for a high-involvement service. Journal of Business Research, 29(1), 1-12. 
[89]Keller, K. L. (1993). Conceptualizing, measuring, and managing customer-based brand equity. Journal of Marketing, 57, 1-22. Lutman, M. R. (1991). End-benefit segmentation and prototypical bonding. Journal of Advertising Research, 31(3), 9-18.

[90]Badenhausen, K. (1996, July 8). Blind faith. Financial World, pp. 50-55.

[91] Aaker, D. A. (1991). Managing brand equity. New York: Free Press.

[92] Starčević, S. (2013). Istraživanjek on ceptaličnostibrenda u marketingu. Marketing, 44(2), p. 149-172.

[93]Fournier, S. (1998). Consumers and their brands: Developing relationship theory in consumer research. Journal of Consumer Research, 24(4), p. 343-373.

[94]Lavidge, R.J. and Steiner, G.A., A Model for Predictive Measures of Advertising Effectiveness. Journal of Marketing, October 1961, pp 59-62

[95] Ganesha, H. R., Aithal, P. S.,\& Kirubadevi, P. (2020). Experimental Investigation of Cannibalisation by Introducing a Global Brand Abreast Existing Indian Store Brand. International Journal of Applied Engineering and Management Letters (IJAEML), 4(1), 10-19.

[96] Ganesha, H. R., Aithal, P. S., \& Kirubadevi, P. (2020). Input and Output Driven Sales Personnel Performance Measures: Insights from an Experiment. International Journal of Case Studies in Business, IT, and Education (IJCSBE), 4(1), 2337.

[97] Ganesha, H. R., Aithal, P. S., \& Kirubadevi, P. (2020). Need-Based Sales Pitch: Insights from an Experiment. International Journal of Case Studies in Business, IT, and Education (IJCSBE), 4(1), 79-87.

[98] Ganesha, H. R., Aithal, P. S., \& Kirubadevi, P. (2020). Integrated Inventory Management Control Framework. International Journal of Management, Technology, and Social Sciences (IJMTS), 5(1), 147-157.

[99] Ganesha, H. R., Aithal, P. S. \& Kirubadevi, P. (2020). Optimal Category Mix in Multi-Category
Retailing - Insights from an Experiment. International Journal of Case Studies in Business, IT, and Education (IJCSBE), 4(1), 112-126.

[100] Ganesha, H. R., Aithal, P. S., \& Kirubadevi, P. (2020). Changes in Consumer Perspective towards Discount at Brick-and-Mortar Stores owing to Emergence of Online Store Format in India. International Journal of Management, Technology, and Social Sciences (IJMTS), 5(1), 43-83.

[101] Ganesha, H. R., Aithal, P. S., \& Kirubadevi, P. (2020). Short-Term Discounting Frameworks: Insights from Multiple Experiments. International Journal of Case Studies in Business, IT, and Education (IJCSBE), 4(1), 8-22.

[102] Ganesha, H. R., Aithal, P. S., \& Kirubadevi, P. (2020). Long-Term Discounting Frameworks: Insights from Multiple Experiments. International Journal of Management, Technology, and Social Sciences (IJMTS), 5(1), 84-100.

[103] Ganesha, H. R., Aithal, P. S., \& Kirubadevi, P. (2020). Decentralized Discounting Framework: Insights from an Experiment. International Journal of Applied Engineering and Management Letters (IJAEML), 4(1), 20-40.

[104] Ganesha, H. R., Aithal, P. S. \& Kirubadevi, P. (2020). Integrated Discounting Framework for Indian Brick-and-Mortar Retailers. International Journal of Management, Technology, and Social Sciences (IJMTS), 5(1), 110-123.

[105] Ganesha, H. R., Aithal, P. S. \& Kirubadevi, P. (2020). Impact of Store Size Reduction on Overall Store Performance - Insights from an Experiment. International Journal of Case Studies in Business, IT, and Education (IJCSBE), 4(1), 103-111.

[106] Ganesha, H. R., Aithal, P. S. \& Kirubadevi, P. (2020). Consumer Affordability in Tier-1, Tier-2 and Tier-3 Cities of India - An Empirical Study. International Journal of Applied Engineering and Management Letters (IJAEML), 4(1), 156-171. 
[107] Ganesha, H. R., Aithal, P. S. \& Kirubadevi, P. (2020). Ideal Store Locations for Indian Retailers - An Empirical Study. International Journal of Management, Technology, and Social Sciences (IJMTS), 5(1), 215-226.

[108] Ganesha, H. R., Aithal, P. S., \& Kirubadevi, P. (2020). An Integrated Framework to Derive Optimal Number of Sales Personnel for a Retail Store. International Journal of Applied Engineering and Management Letters (IJAEML), 4(1), 41-50.

[109] Ganesha, H. R., \& Aithal, P. S. \& Kirubadevi, (2020). Integrated Marketing Mix Framework for Baby Care Retailing in India. International Journal of Applied Engineering and Management Letters (IJAEML), 4(1), 191-218. 